\title{
STUDI PERILAKU PETUGAS PARAMEDIS DAN CLEANING SERVICE DALAM PENGELOLAAN LIMBAH MEDIS PADAT DI RSUD DR SOETOMO SURABAYA
}

\author{
Fransisca Fitri Novitasari, Sri Mardoyo, Sukiran Al Jauhari
}

\begin{abstract}
Rumah Sakit Umum Daerah Dr. Soetomo, Surabaya as one of medical service means, is a place where both sick and healthy people are gathering together. Activities of RSUD Dr. Soetomo will produce solid and liquid medical waste thatmay affect ennironmental pollution and health disorder. The behavior of Paramedic and Cleaning Service personnel significantly affect in managing the solid medical waste management.

This research is a descriptive one, namely a research method aimin to assess the behavior of Paramedic and Cleaning Service personnel, comprising of knowledge level, attitude, and action in managing those solid medical wastes in Rumah Sakit Umum Daerah Dr. Soetomo, Surabaya. Population in this research was 298 Paramedic and Cleaning Service Personnel, spread in 13 wards, total sample was 75 Paramedic personnel and 3 Cleaning Service personnel. Data obtained was further analyzed descriptively with table.

The research result on solid medical waste management in Rumah Sakit Umum Daerah Dr. Soetomo Surabaya, having satisfactorily knowledge level assessment each was $50,6 \%$ for Paramedic personnel and $67 \%$ for Cleaning Service personnel. While for satisfactorily attitude assement was $53,3 \%$ for Paramedic personnel and $100 \%$ for Cleaning Service personnel. Regarding satisfactorily performance assessment, it was achieved of $18,6 \%$ for Paramedic personnel, and $0 \%$ for Cleaning Service personnel.

Following the observation result of Paramedic and Cleaning Service personnel, it is suggested for their further guidance and briefing in behavior improvement regarding solid medical waste management.
\end{abstract}

\section{Keywords : Behavior, Hospital}

\section{PENDAHULUAN \\ Latar Belakang}

Menurut Keputusan Menteri

Kesehatan Republik Indonesia Nomor

1204/MENKES/SK/X/2004 tentang

Persyaratan Kesehatan Lingkungan Rumah

Sakit dinyatakan bahwa rumah sakit sebagai sarana pelayanan kesehatan, tempat berkumpulnya orang sakit maupun orang sehat, atau dapat menjadi tempat penularan penyakit serta memungkinkan terjadinya pencemaran lingkungan dan gangguan kesehatan.

Berbagai dampak yang ditimbulkan oleh limbah medis padat, karena banyak bahan yang terkandung di dalamnya yang dapat menimbulkan dampak kesehatan. Limbah medis secara garis besar dapat digolongkan menjadi limbah medis dan limbah non medis. Rumah sakit merupakan penghasil limbah medis terbesar. Berbagai jenis limbah yang dihasilkan di rumah sakit dan unit-unit pelayanan kesehatan bisa membahayakan dan menimbulkan gangguan kesehatan bagi pengunjung dan terutama kepada petugas yang menangani limbah tersebut serta masyarakat sekitar rumah sakit. Limbah medis tersebut memerlukan pengelolaan. (Depkes,RI 1995).

Petugas yang menangani limbah medis mempunyai resiko terhadap penyakit yang dihadapi petugas kesehatan oleh karena kuman penyakit dari penyakit AIDS, Infeksi Kulit, Antraks, Mengitis, Demam Berdarah, Septikemia, Bakteriemia, Kandidemia, Hepatitis A, Hepatitis B dan C terdapat didalam limbah medis. Kuman yang terdapat di dalam darah tersebut ditularkan lewat darah. Resiko tertular penyakit ini paling besar terjadi apabila orang tertusuk benda limbah yang tajam atau runcing karena benda itu dapat merusak kulit. Lewat luka itu virus dan kuman lainnya masuk ke dalam tubuh. (Reinhardt, 1995, hal 113).

Dari pernyataan tersebut maka perilaku sangat berpengaruh terhadap petugas 
dalam menangani limbah medis padat agar tidak terjadi tertularnya penyakit. Adapun perilaku kesehatan adalah suatu respons seseorang (organisme) terhadap stimulus atau obyek yang berkaitan dengan sakit dan penyakit, sistem pelayanan kesehatan, makanan dan minuman, serta lingkungan. (Notoadmodjo, 2012, hal 134).

Dari observasi awal ditemukan masalah dalam pengelolaan limbah medis padat yaitu tidak ada pemisahan antara limbah benda tajam (jarum) dengan limbah infeksius lainnya (seperti; jaringan, pembalut luka bedah, pakaian yang terinfeksi darah pasien, limbah yang sudah tersentuh pasien yang menjalani Haemodialisis), masih banyak ditemukan limbah medis padat di TPS (tempat pembuangan sampah sementara) limbah non medis, tidak ada pelabelan untuk limbah medisnya, untuk petugas tidak menggunakan APD pada saat pemilahan dan pengangkutan limbah medis.

\section{Tujuan Penelitian}

Untuk mengetahui perilaku petugas Paramedis dan Cleaning Service dalam pengelolaan limbah medis padat di RSUD Dr. Soetomo Surabaya.

\section{METODE PENELITIAN \\ Jenis Penelitian}

Penelitian ini merupakan penelitian deskriptif yaitu penelitian yang dilakukan untuk menggambarkan suatu keadaan didalam suatu komunitas atau masyarakat. Penelitian ini dilakukan dengan pendekatan cross sectional di mana variabel yang termasuk faktor risiko dan variabel yang termasuk efek diobservasi sekaligus pada waktu yang sama karena pengamatan hanya dilakukan pada satu waktu tertentu

\section{HASIL PENELITIAN DAN PEMBAHASAN \\ Tingkat Pengetahuan Petugas Para- medis}

Tingkat pengetahuan Petugas Paramedis di RSUD Dr Soetomo Surabaya tentang pengelolaan limbah medis padat memperoleh kriteria "Baik" 50,6\%, "Cukup" $44 \%$ dan "Kurang" 5,3\%. Sebagian besar yang memperoleh kriteria "Baik" 50,6\%, Ini disebabkan karena Instalasi Sanitasi Lingkungan (ISL) RSUD $\mathrm{Dr}$ Soetomo Surabaya telah melakukan koordinasi dan sosialisasi kepada kepala unit perawatan dan tidak dilakukan penelitian lain untuk di perbandingkan. (Notoatmodjo, 2010).

\section{Lokasi dan Waktu Penelitian}

Penelitian dilakukan di Rumah Sakit Umum Daerah Dr. Soetomo Surabaya yang terletak di Jalan Mayjend Prof. Dr. Moestopo 6-8 Surabaya. Penelitian dilaksanakan pada bulan Mei 2013

\section{Populasi dan Sampel}

Populasi yang digunakan dalam penelitian ini adalah petugas paramedis yang berhubungan dengan pengelolaan limbah medis padat (penimbulan limbah, pemilahan, pewadahan, pemanfaatan kembali, tempat penyimpanan sementara, pengangkutan, pemusnahan dan pembuangan akhir). Petugas Paramedis yang berjumlah 295 orang dan tersebar di 13 ruangan. Dan Petugas Cleaning Sevice yang berjumlah 3 orang. Sampel dalam penelitian ini adalah populasi yang diambil secara proporsional random sampling sebanyak 75 petugas Paramedis dan 3 petugas Cleaning Service. Cara pengambilan sampel petugas tiap ruangan untuk menentukan besar sampel pada tiaptiap unit pelayanan kesehatan dilakukan secara proposional.

\section{Variabel Penelitian}

Variabel dalam penelitian ini adalah pengetahuan, sikap, tindakan petugas Paramedis dan Cleaning Service dalam pengelolaan limbah medis padat di RSUD Dr Soetomo Surabaya.

\section{Metode Analisis Data}

Data yang telah terkumpul, kemudian dilakukan editing, coding, tabulasi data, analisis.

pasien serta monitoring dan evaluasi tentang pengelolaan limbah medis padat secara rutin setiap hari. Dan oleh sebab itu sebagaian besar Petugas Paramedis sudah mengetahui tentang limbah medis dan pengelolaannya. Sedangkan yang memperoleh kriteria "Cukup" 44\% dan "Kurang" 5,3\%. Yang memperoleh kriteria "Kurang" 5,3\% disebabkan karena kurangnya pengetahuan petugas paramedis terhadap pengelolaan limbah medis padat dalam pengertian, sumber, jenis, persyaratan, dan tata laksana pengelolaan limbah medis padat. 


\section{Tingkat Pengetahuan Petugas Cleaning Service}

Tingkat pengetahuan Petugas Cleaning Service di RSUD Dr Soetomo Surabaya tentang Pengelolaan limbah medis padat (transportasi, pengolahan, pemusnahan, dan Pembuangan akhir limbah medis padat). Sebagian besar memperoleh kriteria "Baik" 67\% "Cukup" 33\% dan "Kurang" $0 \%$, Ini disebabkan Instalasi Sanitasi Lingkungan (ISL) RSUD Dr Soetomo Surabaya telah melakukan koordinasi dengan pengawas CS, pembinaan dan penyuluhan terhadap petugas Cleaning Service serta monitoring dan evaluasi secara rutin tentang pengelolaan limbah medis padat. Sehingga sebagian besar Petugas Cleaning Service sudah mengetahui tentang limbah medis dan pengelolaanya.

\section{Sikap Petugas Paramedis}

Sikap Petugas Paramedis di RSUD Dr Soetomo Surabaya tentang pengelolaan limbah medis padat memperoleh kriteria "Baik" 53,3\%, "Cukup" 37,3\%, dan "Kurang" 9,3\%. Sebagaian besar yang memperoleh kriteria penilaian "Baik" $53,3 \%$, Ini disebabkan karena sebagaian besar Petugas Paramedis sudah mengetahui tentang limbah medis dan pengelolaannya. Sehingga mereka juga mempunyai respon positif/setuju tentang pengelolaan limbah medis padat. Sedangkan yang memperoleh kriteria "Cukup" 37,3\% dan "Kurang" 9,3\%. Yang memperoleh kriteria "Kurang" 9,3\% disebabkan petugas sangat tidak setuju limbah medis plastik ditampung pada tempat khusus, terpisah dari limbah medis lainnya. Hal ini juga disebabkan karena kurangnya pengetahuan petugas paramedis terhadap pengelolaan limbah medis padat khususnya pada penampungan limbah. Dengan limbah berada dalam kantong atau kontainer yang sama penyimpanan, pengangkutan dan pembuangan akan mengurangi kemungkinan kesalahan petugas dan penanganannya.

\section{Sikap Petugas Cleaning Service}

Sebagian besar sikap Petugas Cleaning Service di RSUD Dr Soetomo Surabaya positif tentang pengelolaan limbah medis padat yaitu sebesar $100 \%$. Hal ini karena petugas Cleaning Service sudah mempunyai tingkat pengetahuan yang baik sehingga mereka juga mempunyai respon positif/setuju tentang pengelolaan limbah medis padat.

\section{Tindakan Petugas Paramedis}

Petugas Paramedis di RSUD Dr Soetomo tentang pengelolaan limbah medis padat, dari 75 Responden yang mempunyai tingkat pengetahuan dan sikap yang baik tidak selalu diikuti oleh tindakan yang baik pula atau sesuai prosedur/SOP. Hal ini terlihat dari hasil observasi mengenai tindakan Petugas Paramedis yang memperoleh kriteria "Baik" sebesar 18,6\%, "Cukup" sebesar 53,3\% dan "Kurang" sebesar $28 \%$.diantaranya adalah : Proses pemilahan limbah medis dan non medis pada tahap penimbulan masih jarang dilakukan. Hal tersebut juga disebabkan kurangnya kepedulian petugas paramedis terhadap pengelolaan limbah medis padat dengan prosentase sebesar 10,6\%. Banyaknya pasien yang dirawat, jumlah petugas paramedis tidak sebanding dengan jumlah pasien menyebabkan tingkat kejenuhan dan kebingungan pada petugas paramedis sehingga dapat mempengaruhi tingkat kepedulian petugas paramedis dalam proses pemilahan limbah medis, Pemilahan limbah plastik dari hasil observasi diperoleh yang "Jarang" melakukan sebanyak 13,3\%. Hal ini disebabkan RSUD Dr Soetomo Surabaya tidak memiliki "Safety box" dan tempat khusus untuk limbah plastik yang disebabkan terbatasnya anggaran yang tersedia, Pemilahan limbah benda tajam (jarum) dari hasil observasi diperoleh yang "Jarang" melakukan sebanyak 13,3\%. Hal ini disebabkan belum ada laporan terjadinya kecelakaan kerja akibat jarum suntik menyebabkan kurangnya kepedulian dari pihak manajerial tentang hai tersebut, Tidak semua Petugas Paramedis selalu menggunakan APD (Alat Pelindung Diri) pada saat melakukan perawatan terhadap pasien. Hal ini disebabkan jumlah APD yang tersedia terbatas.

\section{Tindakan Petugas Cleaning Service}

Tindakan Petugas Cleaning Service yang memperoleh kriteria "Baik" sebesar $0 \%$. Sedangkan yang memperoleh kriteria penilaian "Cukup" 33\% dan "Kurang" 67\%. Hal ini disebabkan masih terdapat Petugas Cleaning Service yang tidak sesuai SOP diantaranya adalah : Petugas Cleaning Service tidak selalu/jarang menggunakan APD (Alat Pelindung Diri) dengan 
prosentase sebesar $100 \%$. Hal ini disebabkan jumlah APD yang tersedia terbatas dan hanya berupa masker dan sarung tangan, sedangkan pihak ketiga tidak menyediakan APD untuk petugas Cleaning Service. Sehingga petugas Cleaning Service rentan tertular penyakit seperti Hepatitis B, HIV, dan penyakit lainnya, Tempat sampah medis jarang dilakukan pencucian dan desinfeksi dengan prosentase $66,6 \%$. Hal ini disebabkan tempat sampah medis sudah dilapisi kantong kresek sehingga jarang terlihat kotor, Limbah medis diangkut dengan menggunakan troli / kereta sampah yang tidak tertutup dengan prosentase sebesar $100 \%$. Hal ini disebabkan kelebihan muatan kantong plastik limbah medis didalam troli sehingga terjadi tumpahan selama penanganan dan pengangkutan.

\section{KESIMPULAN}

\section{Tingkat Pengetahuan}

Tingkat pengetahuan Petugas Paramedis dan Cleaning Service di RSUD Dr Soetomo Surabaya tentang pengelolaan limbah medis padat sebagian besar memperoleh kriteria penilaian baik yaitu $50,6 \%$ untuk Petugas Paramedis dan $67 \%$ untuk Cleaning Service. Hal ini disebabkan karena sebagian besar Petugas Paramedis dan Cleaning Service sudah mengetahui tentang limbah medis dan pengelolaanya.

\section{Sikap}

Untuk sikap Petugas Paramedis dan Cleaning Service di RSUD Dr Soetomo Surabaya tentang pengelolaan limbah medis padat sebagian besar mempunyai sikap positif dengan kriteria penilaian baik yaitu $53,3 \%$ untuk Petugas Paramedis dan $100 \%$ untuk petugas Cleaning Service di RSUD Dr Soetomo Surabaya memahami dan mempunyai apresiasi positif tentang pentingnya pengelolaan limbah medis padat dilingkungan rumah sakit.

\section{Tindakan}

Dari hasil observasi tindakan Petugas Paramedis di RSUD Dr Soetomo Surabaya tentang pengelolaan limbah medis padat memperoleh kriteria "Cukup" sebesar $53,3 \%$ dan "Kurang" sebesar 28\%. Hal ini disebabkan karena beberapa faktor dukungan dan fasilitas yang tidak memadai, kelebihan beban tugas yaitu dengan adanya pasien yang lebih seperti jumlah pasien dirawat dengan jumlah petugas yang tidak sebanding sehingga tingkat kejenuhan dan kebingungan pada petugas paramedis dan mempengaruhi tingkat kepedulian petugas paramedis dalam proses pemilahan limbah medis, serta jumlah dan jenis APD yang tidak memadai. Sedangkan hasil penilaian tindakan Cleaning Service sebagian besar memperoleh kriteria penilaian baik sebesar $0 \%$. Hal ini disebabkan petugas Cleaning Service yang selalu jarang menggunakan APD dikarenakan persediaan jumlah dan jenis APD yang kurang memadai.

\section{SARAN}

1. Mengenai perilaku petugas baik Paramedis maupun Cleaning Service dalam pengetahuan limbah medis perlu ditingkatkan dengan langkah-langkah seperti :

1) Koordinasi petugas sanitarian selaku penaggung jawab pengelolaan limbah medis padat dengan pihak kepala ruangan perawatan pasien selaku penanggung jawab petugas paramedis tentang perilaku pengelolaan limbah medis padat.

2) Supervisi oleh petugas sanitarian untuk mengevaluasi pengelolaan limbah medis padat khususnya pada ruangan pelayanan kesehatan.

3) Pembinaan dan penyuluhan kepada petugas Cleaning Service tentang pengelolaan limbah medis padat.

2. Untuk peningkatan dan perbaikan petugas dalam pengelolaan limbah medis padat di RSUD $\mathrm{Dr}$ Soetomo Surabaya, upaya yang dilakukan adalah :

1) Melakukan desinfeksi terhadap bak limbah medis secara rutin setiap hari agar petugas tidak terkontaminasi limbah medis padat.

2) Melakukan pewadahan dan pelabelan limbah medis padat sesuai dengan pedoman yang telah ditentukan oleh KepMenkes RI No 1204 Tahun 2004.

3) Mengganti bak pengumpul yang lebih besar untuk menampung limbah medis padat.

4) Disediakan APD dengan jumlah yang memadai bagi Petugas Paramedis berupa sarung tangan, masker, baju kerja, topi dan kaca mata. 
DAFTAR PUSTAKA

Akademi Kesehatan Lingkungan, 2011. Pedoman Penulisan Karya Tulis. Surabaya : Akademi Kesehatan Lingkungan.

Departemen Kesehatan RI, 1995. Pedoman Sanitasi Rumah Sakit di Indonesia. Jakaarta : Direktorat Jenderal PPM \& PLP

Departemen Kesehatan RI, 1996. Pedoman Teknis Pengelolaan Limbah Klinis dan Desinfeksi \& Sterilisasi di Rumah Sakit. Jakarta : Direktorat Jenderal PPM \& PLP

Direktorat Jendral Pemberantasan Penyakit Menular dan Penyehatan Lingkungan ,2013. Keputusan Menteri Kesehatan RI nomor 1204/MenKes/SK/X/2004 tentang persyaratan kesehatan lingkungan rumah sakit. 16 Maret 2013.

Notoadmojo, Soekidjo, 2010. Metodologi Penelitian Kesehatan, Jakarta : Rineka Cipta

Notoatmodjo, Soekidjo, 2012. Promosi Kesehatan dan Perilaku Kesehatan, Jakarta : Ríneka Cipta

Notoatmodjo, Soekidjo,2003. Pendidikan dan Perilaku Kesehatan, Jakarta : Rineka Cipta
Reindhardt, Peter dkk, 1995. Pengelolaan Limbah Menular dan Limbah Medik. Jakarta : Akademi Kesehatan Lingkungan Depkes RI

Sanropie, Djasio dkk, 1989. Komponen Sanitasi Rumah Sakit untuk Industri Lembaga Pendidikan Tenaga Sanitasi. Jakarta : Departemen Kesehatan RI Proyek Pengembangan Pendidikan Tenaga Sanitasi Pusat dan Tenaga Kesehatan

Sarudji, Didik, 1985. Pengelolahan Sampah. Surabaya : Akademik Penilik Kesehatan.

Trisnawati,Lydias. 2012. Studi Tentang Perilaku Petugas Terhadap Pengolahan Limbah Medis Padat di UTD PMI Cabang Surabaya Tahun 2009. Dalam : Karya Tulis Ilmiah, Politeknik Kesehatan,Kementrian Kesehatan Surabaya.

World Health Organization, 2005. Pengelolaan Aman Limbah Layanan Kesehatan. Editor : A. Pruss, dkk. Penerbit Buku Kedokteran (EGC). 